\title{
A preocupação com a origem: história e metafísica
}

Thelma Silveira da M otta Lessa da Fonseca

thelessa@uol.com.br

Universidade Federal de São Carlos, São Carlos, São Paulo, Brasil

resumo 0 texto que se segue busca apresentar algumas facetas da discussão sobre a origem da linguagem em Rousseau, Fichte e Nietzsche com vistas a destacar elementos comuns aos três autores, sobretudo ao tomarem o ponto de vista histórico como estratégia de recusa de toda fundamentação metafísica da palavra.

palavras-chave linguagem; origem; história; Rousseau; Fichte; Nietzsche.

É bastante curioso o volteio retórico de Sócrates ao apresentar a ideia de determinação natural justamente como argumento contrário aos pressupostos transcendentes atribuídos por ele à compreensão da linguagem como convenção. 0 impasse que resulta na aporia final do diálogo parece ser gerado neste ponto, já que a convicção nominalista de H ermógenes se verá abalada diante da acusação de supor uma fundamentação metafísica:

Talvez pareça ridículo, $\mathrm{H}$ ermógenes, dizer que as letras e as sílabas revelam as coisas imitando- as; entretanto, é necessário que assim seja, pois nós não temos nada de melhor a que pudéssemos nos reportar sobre a verdade dos nomes primitivos, a menos que você queira, a exemplo dos poetas trágicos que, logo que se veem embaraçados, recorrem às máquinas, elevando deuses nos ares, nós nos furtaríamos ao trabalho como eles, dizendo que os nomes primitivos foram estabelecidos pelos deuses e são exatos por essa razão (PLATÃ O,1967, p. $451,425 c-426 b$ )

R ecebido em 22 de maio de 2011. A ceito em 3 de junho de 2011. doispontos, Curitiba, São Carlos, vol. 8, n. 1, p.127-143, abril, 2011 


\section{8}

N os séculos XVIII e XIX, a discussão sobre a origem da linguagem ganha outro feitio. Porém, se a ideia da determinação natural é descartada, a sombra da metafísica está, ainda, para ser dissi pada. N ão se trata mais de recusar um dos pólos dessa dupla alternativa em favor do outro, mas, antes, de reformular o problema em termos diversos. Agora, a ingenuidade ao se atribuir a constituição da linguagem a determinações naturais é que incorreria no perigo de reinserir pressupostos metafísicos naquilo que, doravante, deve ser entendido como criação humana, seja pela razão, pelo entendimento, pela imaginação ou pelo sentimento.

Vemos em R ousseau e em Fichtel uma tentativa de reconstituição histórica daquilo que em ambos se denomina "invenção da língua" 2 com a finalidade de excluir qualquer ideia de linguagem como espelhamento ou reflexo da natureza, já que esse tipo de compreensão representaria, num caso, a recaída na metafísica ingênua e, noutro, o recuo ao dogmatismo pré-crítico. No entanto, a alternativa defendida por Hermógenes, que talvez hoje chamássemos de linguagem como "acordo intersubjetivo" ou coisa similar, tampouco parecerá plausível a esses autores por diferentes motivos, mas, basicamente, ou sobretudo por não Ihes parecer sensato acolher a ideia de consenso na fixação dos nomes primitivos. Por isso, ao se colocar de lado a compreensão da origem da linguagem como phúsei, surge o problema de explicar a uniformidade da linguagem estabelecida para fins de comunicação. A alternativa thései, ao contrário do que ocorre com al guns pensadores do século XX, não os satiffaz.

Seria possível dizer que esses autores se recusam a cair na armadilha astuciosamente montada por C rátilo, já que buscam desviar-se da facilidade da solução dada pelo recurso à determinação natural, ao mesmo tempo em que desdenham da ingenuidade da tese artificialista de H ermógenes, essa, incapaz de abarcar a compreensão dos nomes primitivos. 0 dualismo do diálogo platônico será dissolvido com a mudança de determinados pontos de vista: a natureza deixará de ser exclusivamente exterior e a linguagem primeira se constituirá como expressão do sentimento ( $R$ ousseau) ou do pensamento (Fichte) o que torna a linguagem reflexo, imitação mas, aí, de uma interioridade que é constitutiva do objeto; a questão dos nomes primitivos cederá lugar para a ideia de invenção da duração (e sua derivação, a substância) necessária ao estabelecimento dos substantivos, al go que se distancia da mutabilidade dada na percepção. 
A questão que começa a se desenhar com esse novo panorama se sustenta sobre uma pergunta: passa a ser problemática a dificuldade de se alcançar uma explicação para a origem da linguagem, já que essa criação se dá no plano das ações humanas. Daí o recurso às hipóteses voltadas para reconstituições históricas que, num efforço imaginativo, mais do que antropológico, buscam atribuir ao plano humano o surgimento da linguagem, ao mesmo tempo em que desvendam o tipo de relação entre os homens em que tal criação teria podido alcançar lugar, sejam eles membros da comunidade, indivíduos em sua existência esparsa no estado de natureza, ou componentes casuais das hordas primitivas.

$\mathrm{D}$ efrontando-se com o mesmo problema, o jovem $\mathrm{N}$ ietzsche retoma a discussão, mas reformula a questão a partir de outro ponto de vista: aqui não mais se tratará de investigar a origem histórica da linguagem mas de problematizar a inapreensibilidade desta origem na história da filosofia.

\section{Rousseau}

N o D iscurso sobre a origem e os fundamentos da desigualdade entre os homens $R$ ousseau apresenta duas diferenças entre 0 homem e 0 animal: sua qualidade de agente livre e a faculdade de aperfeiçoar-se ou perfectibilidade.

$Q$ uanto à liberdade, os animais são desprovidos dela e orientam suas ações guiados unicamente pelo instinto, que apenas segue as prescrições da natureza, como se sabe. 0 clássico exemplo é o do gato, que pode morrer de fome ao lado de uma cesta de frutas. 0 homem também orienta seu comportamento pelos instintos, age conforme as determinações naturais, mas realiza duas "operações da alma", as primeiras operações: desejar/ querer e temer/ não querer. Tais operações são um refinamento das necessidades naturais: o querer e 0 temer nascem das necessidades, do princípio natural da auto-conservação.Vale lembrar que essa diferença entre homens e animais provém das paixões, e não do entendimento e nem da razão que, aliás, desenvolve-se exclusivamente para servir as paixões, sendo, portanto, derivada.

A segunda diferença, a perfectibilidade, é ligada á primeira. Diferentemente dos animais o homem encontra em si, em meio às demais faculdades, a faculdade de aperfeiçoar-se: trata-se de uma faculdade de desen- 


\section{0}

volver outras faculdades, e por meio dela escapa, por assim dizer, da pura determinação natural.

Enquanto os animais já têm desde o nascimento um número restrito de faculdades e, portanto, de habilidades a serem desenvolvidas e colocadas em prática, o homem, além dessas possui uma faculdade que the abre portas para o desenvolvimento de habilidades imprevisíveis. Bem, como sabemos é daí que se explica o surgimento do entendimento (ou razão, termos intercambiáveis no Segundo D isarso).

Pode-se, portanto, resumir o trajeto da seguinte maneira: as necessidades geram paixões que, após o C ontrato, constituem o entendimento. A questão que se coloca é: em que ponto dessa cadeia surge a linguagem? Seria a língua uma expressão das paixões ou um instrumento da razão?

Para R ousseau, o problema está em saber se já havia alguma espécie de sociedade quando da invenção da linguagem. A ssim, a pergunta é: como as línguas se tornaram necessárias? Algumas hipóteses explicativas são rapidamente descartadas por ele:

1. A linguagem não pode ter sido criada no seio da família, já que esta não estava constituída no estado de natureza. M esmo em se considerando a restrita convivência entre mãe e filho, e mesmo que se suponha que entre ambos pudesse ter se instituído al guma forma de comunicação, esta rapidamente se desvaneceria com o rompimento dos laços maternos. D e qualquer forma, essa suposição não daria conta de explicar o surgimento da língua enquanto linguagem instituída, uniformizada para uma coletividade inteira.

2. Tampouco se poderia dizer que o problema ficaria resolvido ao se supor que a mãe ensinaria o filho a utilizar determinadas designações, já que isso não explicaria o surgimento da linguagem, mas apenas sua reprodução.

Com isso se vê que R ousseau está, nesse texto, considerando o problema do surgimento da linguagem enquanto sistema articulado, padronizado e que sirva à comunicação.

3. Como terceira suposição, pode-se pensar que a linguagem tenha surgido para auxiliar o pensamento. M as aí surge um novo problema: "se os homens tiveram necessidade da palavra para aprender a pensar, tiveram muito mais necessidade de saber pensar para encontrar a arte da palavra" (R O U SSEAU ,1973a, p.247)33. 
0 grande problema, portanto, está em saber se a linguagem é posterior ao contrato, anterior a esse ou contemporânea dele. A parentemente, o estabelecimento da sociedade organizada exigiria, uma comunicação prévia, a não ser que imaginássemos uma situação de emergência tal que colocasse os homens primitivos em um acordo tácito sobre sua codependência de forma que, sem palavra ou gesto compartilhado algum, esses indivíduos, contrariando sua natural propensão ao isolamento, optassem pela confraternização. Porém, sabemos que a linguagem é dispensável ao homem no estado de natureza, embora a vida em sociedade seja inconcebível sem ela. A ssim, a mesma dificuldade existente ao se buscar explicar a origem do contrato se aplica à explicação do surgimento da linguagem. M ais do que isso, pode-se até dizer, ao que tudo indica, que a discussão sobre origem da linguagem sintetiza todas as dificuldades que caracterizam a explicação da passagem da natureza à sociedade entendida como ruptura.

Tais dificuldades decorrem do fato de que a palavra é entendida como arte: R ousseau é nominalista. $\mathrm{N}$ ão haveria problema algum se o falar fosse resultado de uma simples determinação natural. Enfim, R ousseau abdica, nesse texto, de resolver a questão sobre o que é fundante no processo, a sociedade ou a linguagem e curiosamente conclui que teria sido impossível dizer que as línguas nasceram por meios puramente humanos. "Puramente humanos" remete, certamente, ao homem tal como é essencialmente, na natureza:

0 homem encontra unicamente no instinto todo o necessário para viver no estado de natureza; numa razão cultivada só encontra aquilo que é necessário para viver em sociedade (R O U SSEAU, 1973a, p.251).

No que se refere a um possível utilitarismo existente na origem da linguagem, no E nsaio sobre a origem das línguas, R ousseau parece um crítico do autor do Segundo D iscurso quando diz: "P retende-se que os homens inventaram a palavra para ex primir suas necessidades; tal opinião me parece insustentável" (RO U SSEAU, 1973b, p.163). A gora, a necessidade na natureza causaria a separação e jamais a união entre os homens. Essa origem estaria nas paixões, que não guardam relação necessária alguma com as necessidades naturais: "as primeiras línguas foram cantantes e apaixonadas antes de serem simples e metódicas" (R O U SSEAU , 1973b, p.164). 


\section{2}

Ainda que voltada para a comunicação, a primeira língua não teria finalidade pragmática. Seus termos não eram designações de nomes próprios, mas alegorias, figuras de linguagem cuja musicalidade viria a suscitar emoções no ouvinte, de forma bem próxima àquilo queA ristóteles chamou "retórica" 4 . Sendo a primeira língua criada pelo homem primitivo, ela não teria como objetivo o desvelamento da natureza ou 0 conhecimento do mundo em sua suposta objetividade, mas, antes, teria se constituído unicamente como forma de expressão das paixões. Afinal, como bem descreve Starobinski:

$\mathrm{N}$ o estado de dispersão que R ousseau imagina a humanidade primitiva, nada une 0 indivíduo a seu semelhante, mas nada igualmente o escraviza. N ão experimentando nenhum desejo de comunicação, ele não se sente separado; nenhuma distância metafísica 0 afasta ainda do objeto exterior. Sua relação com o mundo circundante se estabelece no equilíbrio perfeito: o indivíduo faz parte do mundo e o mundo faz parte do indivíduo. Há correlação, acordo harmonizado entre a necessidade, o desejo e o mundo (STARO BIN SK I,1991, p.298)5.

D esta forma, no E nsaio sobre a origem das línguas o problema enfrentado no II D iscurso desaparece: como simples expressão, a linguagem pode surgir no seio da natureza sem que isso represente a instauração de alguma forma de civilização ou mesmo de convivência. 0 uso que o homem civilizado faz da língua, ao torná-la instrumento útil, é o que a corrompe, assim como a própria essência humana é corrompida com o Contrato. Mas, o que importa, é que não há contradição entre natureza e linguagem na medida em que essa é vista como via imediata de expressão das paixões. Tem-se aí uma linguagem que dispensa a razão, "que persuadiria sem convencer e descreveria sem raciocinar" e R ousseau acrescenta: "prolongai essas ideias em todas as suas implicações e vereis que o Crátilo de Platão não é tão ridículo quanto parece ser" (RO U SSEAU , 1973b, p.166).

Entende-se por isso que R ousseau se refere à aporia em que fica estagnada a alternativa artifício/ natureza no $\mathrm{C}$ rátilo, pois apresenta uma concepção de linguagem como arte e que, ao mesmo tempo, surge naturalmente. N outras palavras, é criação humana, artifício, mas, uma vez que é via imediata das paixões naturais, está em pleno acordo com a natureza. 
A ssim, a pergunta apresentada no diálogo platônico pressupõe uma falsa dupla alternativa, o que a torna irrespondível.

\section{Fichte}

Em um pequeno texto intitulado Sobre a capadidade linguística e a origem da língua6, Fichte transita por um universo de problemas bastante semelhante ao percorrido por $R$ ousseau, o que se evidencia logo no início desse escrito:

A primeira questão que se coloca a nós é a seguinte: como o ser humano chegou à ideia de aludir a seus pensamentos por meio de signos voluntários? Essa pergunta contém em si as duas seguintes: 1.0 que levou 0 ser humano à ideia de inventar uma língua? 2. Em que leis naturais reside o fundamento para que esta ideia tenha sido elaborada assim e não de outra forma?É possível encontrar leis que tenham guiado 0 ser humano nessa tarefa?7 (FICHTE, 1846,p. 257/303)

De saída, está descartada nessas considerações a hipótese da origem natural da língua, já que a questão se constrói sobre a pergunta relativa à "invenção" (E rfinden) 8 da palavra para expressão do pensamento. N ão há, assim, lugar para a ideia de que a linguagem primitiva pudesse ser reflexo das coisas mesmas, fruto de uma atividade extra-humana ou anterior à ação do homem. Entretanto, também a ideia de convenção é, como ocorre em R ousseau, colocada de lado:

"Vê-se que em todas as investigações sobre a origem da língua, têm-se baseado excessivamente no acordo voluntário. (...) Linguagem, no sentido mais amplo da palavra, é expressão de nossos pensamentos por signos voluntários" (FICHTE,1846, p. 302/ 256).

Privilegiando a ideia de expressão na invenção das primeiras palavras, Fichte anda, também aqui, proximamente a R ousseau para logo distanciar-se desse ao afirmar que a U rsprache não pode jamais ser entendida como dirigida ao ouvido: a primeira língua se constitui mediante a invenção de símbolos que visam expressar pensamentos por meio da imitação da natureza e para isso as referências visuais e os gestos são os elementos determinantes nesse início. A questão passa a ser, portanto, 


\section{4}

como teria se desenvolvido a linguagem falada, em que os signos tiveram de ser tranformados para serem ouvidos. D e forma bem semelhante à posição de R ousseau, Fichte cogita uma linguagem rudimentar criada no seio da família e pelo patriarca para fins pragmáticos, mas isso não chega a esclarecer como tal linguagem teria se desenvolvido de maneira uniformizada para a horda inteira:

(...) por que não poderia o segundo e o terceiro vizinho a liberdade de denominar a rosa com outro nome? (FICH TE, 1846,II,p. 316/290).

Vê-se que o que está em questão aí é a "liberdade" implicada na criação das denominações primeiras. Compreende-se, portanto, que a uniformização da língua para toda a comunidade exige que se imponha à mai oria a denominação criada individualmente, como se pode verificar a seguir:

N os povos sem cultura sempre haverá uns poucos que têm suficiente cabeça e suficiente vontade para se ocupar da elaboração da língua.

Portanto, aqueles que demonstram a capacidade e a atitude correspondentes a essa difícil tarefa logo ganharão grande influência sobre a horda (...). D essa maneira, a invenção de um patriarca logo se estende para toda a horda (FIC H TE, 1846,II, p. 316/ 290).

A ideia de coerção sobre a maioria pode explicar o surgimento de uma linguagem falada comum, rudimentar e diretamente referida às impressões sensíveis. Tais termos indicam objetos individuais (FIC H TE, 1846, II, p. 316/290), posteriormente são aplicados para denominar espécies (FIC H TE,1846, II, p. 316/290) já que, por analogia, se pode denominar outro objeto particular com a denominação determinada pelo patriarca e, se a prática confirmar, a generalização está feita. 0 exemplo utilizado por Fichte é o do pai que pede ao filho uma rosa e esse Ihe traz algo semelhante àquilo que o pai havia apontado com esse nome. A esse passo se segue a criação dos conceitos genéricosin ${ }^{10}$, um grau mais alto de abstração.

Fichte trata do surgimento da linguagem a partir de uma tentativa de reconstituição histórica e, já que seu empenho se volta para localizar sua origem no decorrer do estabelecimento das ações humanas, pode-se dizer que há aí um esforço no sentido de recusar a essa origem qualquer 
conotação metafísica ou mesmo transcendente. Bem, essa compreensão da origem da linguagem parte da denominação dos objetos sensíveis, ainda que por esse caminho se possa explicar a criação dos conceitos gerais. Por isso, o próximo problema desse texto será explicar a criação dos conceitos abstratos, emblematicamente representados pela palavra "ser". 0 que a distancia dos demais termos é que ela denomina o durável ${ }^{11}$, enquanto a língua em seus estágios anteriores, refletia o sensível, portanto, a mutabilidade:

Algo permanente não é perceptível; mas todas as modificações têm de se referir a algo permanente - a um substrato durável - que é meramente um produto da imaginação. A este substrato se aplica, então, a palavra ser ou é. 12

A palavra "ser" é, assim, entendida como produto, o que definitivamente exclui de sua origem qualquer determinação transcendente. Ela não nos remete imediatamente à substância, nem a nenhum substrato dado a partir de instâncias exteriores ou anteriores às atividades humanas, no caso, à imaginação, especificamente:

Tendo o entendimento comum uma vez chegado à ideia de uma origem transcendente do mundo, logo descobriu também outras ideias espirituais a partir desse alto ponto de vista: a alma, a imortalidade, etc. (FICH TE,1846, p.322/ 298).

Diante disso, entende Fichte que o homem é guiado por um impulso13 de comunicar-se e expor aos outros sua compreensão. É por meio do entendimento do homem comum, portanto, que a linguagem estabelece o mundo transcendente.

\section{Nietzsche}

Ambos os autores mencionados tomam para si a tarefa de discutir as possibilidades de se compreender o surgimento da linguagem, supondo, em alguma medida, que essa origem seja passível de ser desvendada e compreendida. N esse ponto, pode-se cogitar que R ousseau e Fichte são, de forma semelhante, impulsionados pela expectativa de que essa origem 


\section{6}

seja racionalmente apreensível. A abordagem da questão em $\mathrm{N}$ ietzsche difere da de ambos, ao mesmo tempo em que se nutre do percurso feito por esses e por outros autores sobre o tema. A qui não se trata mais de ir à história para reconstituir o surgimento da linguagem, mas de compreender os limites das sucessivas tentativas de circunscrever essa origem no âmbito do racionalmente compreensível.

C omo $\mathrm{R}$ ousseau, o jovem $\mathrm{N}$ ietzsche toma como referência o $\mathrm{C}$ rátilo de Platão. Em suas anotações de 1869 denominadas “D a 0 rigem da Linguagem" a discussão sobre a alternativa convenção/natureza é compreendida da seguinte maneira: trata-se de saber se a linguagem é criada pela atividade humana ou se é determinada por fatores transcendentes, isto é, externos a essa atividade. $\mathrm{N}$ esse pequeno escrito, $\mathrm{N}$ ietzsche apenas faz uma espécie de recenseamento das diferentes apropriações da questão ao longo da história da filosofia desde Platão. 0 que realmente Ihe interessa é notar que nenhum dos autores mencionados chega a uma solução realmente satisfatória para o dilema.

Assim, segundo a leitura de $\mathrm{N}$ ietzsche, a melhor explicação para a aporia em que desemboca a pergunta pela origem da linguagem, ou seja, a melhor forma de compreender a inapreensibilidade da origem da palavra é a seguinte: se nosso pensamento não é capaz de alcançá-la, isso se deve ao fato de que ele próprio, enquanto pensamento consciente, depende da linguagem: "absolutamente impossível um pensamento tão profundo com uma linguagem ruidosa e simplesmente animal" (N IET ZSC HE, 1921, p.467). A obscuridade e o mistério que pairam sobre o surgimento das línguas, os quais levam à crença de que o homem não poderia tê-la criado são decorrentes do fato de que a consciência e, consequentemente, 0 pensamento articulado somente se edificam sobre o solo fornecido pela palavra. Simplesmente não temos capacidade de apreender nada que anteceda o nascimento da linguagem: "A s pessoas se calam sobre a origem da linguagem; não concebem o mundo, os deuses e os homens sem ela" (NIET ZSC HE, 1921, p.469).

Schelling, ao lado de H erder, foi uma das inspirações para a ideia nietzscheana de que a linguagem é contemporânea da consciência. Essa ideia, que aparece desenvolvida nos escritos posteriores ${ }^{14}$, já surge nas anotações do jovem $\mathrm{N}$ ietzsche, professor de filologia clássica. $\mathrm{No}$ final dessas anotações, diz N ietzsche: 
Como nenhuma consciência filosófica e mesmo simplesmente humana é concebível sem a linguagem, não é a consciência que presidiu a criação da linguagem e, entretanto, quanto mais penetramos em sua natureza, mais adquirimos a certeza de que ela ultrapassa por sua profundidade qualquer criação consciente ${ }^{15}$.

$\mathrm{N}$ ietzsche resgata de Schelling a ideia de que a consciência depende da linguagem, ideia essa que justifica o fato de a amplitude e a profundidade da linguagem serem bem mais expressivas do que aquilo que o pensamento consciente pode abarcar.Tal ideia provê $\mathrm{N}$ ietzsche de um meio de recusar a alternativa phúsei tal como estava presente na pergunta dualista formulada pelos gregos, sem ter de recorrer a um deus ex machina. Se entendermos que 0 aparecimento da linguagem se deu inconscientemente (bewusstlosig), pode-se sustentar que ela é obra da atividade humana, que é "artificial", portanto. A linguagem não é um produto da consciência, pois o pensamento consciente seria impossível sem o auxílio da linguagem articulada.

A unidade e a complexidade da linguagem nos levam a crer que sua formação é orientada por uma finalidade. Ela não aparenta ser fruto do acaso. D aí, a tendência a atribuir sua criação a desígnios sobre-humanos. Como explicá-la, então, como sendo fruto de uma atividade humana inconsciente e, concomitantemente, voltada para um fim?

Diante desse problema, $\mathrm{N}$ ietzsche encontra, em suas leituras de H erder16, uma explicação alternativa, isto é, uma explicação capaz de dispensar a hipótese da intervenção divina. Este autor entenderá que a linguagem é resultado de um "impulso" 17 interno, semelhante àquele que impele o feto ao nascimento. Assim, o fato de que o surgimento da linguagem se apresente como processo voltado para uma finalidade e que, ao mesmo tempo, não é movido por intenções conscientes, não exclui que sua origem esteja circunscrita à existência humana.

A partir dessa ideia, N ietzsche encontra na noção de "instinto" (Instinkt) uma explicação para uma atividade voltada para um produto, dirigida para um fim, portanto, mas que não é engendrada por trabalho consciente. Esta vem solucionar o impasse gerado pela ideia de finalidade sem consciência e, neste ponto, $\mathrm{N}$ ietzsche busca, explicitamente, inserirse no universo do pensamento pós- crítico18: 


\section{8}

$\mathrm{N}$ a C rítica do Juízo, ao mesmo tempo em que (K ant) admite a teleologia da natureza como algo efetivo, destaca a surpreendente antinomia de que uma coisa finalizada careça de consciência. Esta é a essência do instinto (N IET ZSC HE, 1921, p.470).

Trata-se de explicar a unicidade e a complexidade da linguagem como algo criado em vista de um fim sem que seja trabalho da consciência. ${ }^{19}$ Entretanto, mais do que solucionar um impasse, tal noção surge no sentido de explicar positivamente o surgimento da linguagem. "Instinto" dá conta de explicar o surgimento de um produto - a linguagem - que "possui demasiada uniformidade para ser trabalho da massa, mas que é complexo demais para constituir resultado de um trabalho individual" (N IETZSCHE, 1921, p.468). Se habitualmente tais características impeliram os pensadores a atribuir a criação das línguas a instâncias supra humanas ou a compreendê-la como reflexo das " coisas" , o "instinto" caracteriza uma determinação aquém da intenção individual ou coletiva, mas presente e atuante na massa e no indivíduo.

A alternativa artifício/ natureza se sustentava sobre dois pares opostos e excludentes: de uma lado, intenção e consciência e, de outro lado, determinação externa e inconsciente. C omo instituída por convenção, a criação da linguagem pelos homens estaria submetida a um fim determinado por estes. $\mathrm{N}$ este caso, o pensamento consciente deveria ser apto a abarcá-la. C omo algo que escapa ao pensamento, ela apenas poderia ser entendida como reflexo das coisas, isto é, instituída por natureza. A compreensão da linguagem como anterior à consciência torna necessário recusar "os ingênuos pontos de vista anteriores: entre os gregos o problema de saber se a linguagem é thései ou phúsei, ou seja, se depende de uma formação arbitrária, por contrato e convenção, ou se o elemento sonoro depende do conteúdo conceitual" (N IETZSCHE, 1921, p.468). Esta alternativa não mais tem lugar quando 0 artifício deixa de ser entendido como sendo, necessariamente, produto da consciência. 0 artificial pode bem ser fruto da criação humana inconsciente, o que nos permite entender que nem tudo o que é criado a despeito de nossa intenção consciente é necessariamente instituído "por natureza".

Com a solução dada pela noção de "Instinkt", não apenas a ideia de origem natural é rechaçada. Também a sua alternativa - a linguagem 
como fruto de uma convenção - perde sentido. Isso ocorre porque, para que a linguagem pudesse ter sido instituída por convenção, seria preciso que o pensamento consciente existisse previamente a esta instituição. $\mathrm{M}$ as, sendo este pensamento dependente das formas linguísticas, fica excluída a hipótese da“ (...) denominação arbitrária debatida ao longo do C ráti10 de P latão: efetivamente, este ponto de vista pressupõe uma linguagem anterior à linguagem" (N IET ZSCHE, 1921, p.469). Se o pensamento apenas pode transcorrer no interior da linguagem, não poderia haver um pensar que precedesse 0 surgimento da linguagem e que estivesse voltado para criála. A ssim, a alternativa " convenção" supõe a existência de uma linguagem que possibilitasse um trabalho do pensamento voltado para criar a linguagem tal como a conhecemos. Além disso, uma convenção supõe a comunicação entre aqueles que irão partilhá-la, e não haveria como explicar um acordo relativo ao estabelecimento de regras para as denominações mais simples (no Crátilo, trata-se do estabelecimento dos nomes primitivos) sem o auxílio da linguagem. Entendendo "convenção" como acordo deliberado, não haveria como explicar: em primeiro lugar, de que maneira os homens teriam estabelecido entre si um acordo, um contrato, relativo a algo tão complexo quanto as regras e normas do uso da linguagem sem que eles dispusessem de uma linguagem articulada; e, em segundo lugar, por que meios os homens tivessem "deliberado" sem 0 auxílio da consciência.

Se a ideia de linguagem como reflexo do mundo é recusada, tampouco a ideia de convenção parece ser convincente. A R ousseau e N ietzsche e, por distintas razões, também a Fichte, é comum a preocupação de inserir 0 problema dessa origem no âmbito da criação e da expressão, separando-a da linguagem enquanto meio de comunicação para fins utilitários. N ão haverá aí espaço para a ideia de definição ostensiva, nem de acordo intersubjetivo, ao menos no que se refere à criação da linguagem. É de $\mathrm{R}$ ousseau que $\mathrm{N}$ ietzsche recupera a ideia da musicalidade da Ü rsprache, seu caráter poético e metafórico. Aproxima-se de Fichte ao considerar a uniformização da língua, ou seja, o estabelecimento de uma linguagem 


\section{0}

aceita por uma coletividade, como fruto de uma coerção sobre a maioria por um indivíduo capaz de fixar a impressão mutável por meio de uma designação. Estes pontos de vista permitem desvincular a ideia de artifício da noção de convenção no sentido estrito, isto é, baseada em um acordo inter pares. N o seguinte trecho, bastante conhecido, de Sobre verdade e mentira no sentido ex tra-moral, ambas as posições de $\mathrm{N}$ ietzsche se evidenciam:

C ontinuamos sem saber de onde provém o impulso à verdade: pois até agora ao ouvimos falar da obrigação que a sociedade, para existir, estabelece: de dizer a verdade, isto é, de usar as metáforas usuais, portanto, expresso moralmente: da obrigação de mentir segundo uma convenção sólida, mentir em rebanho, em estilo obrigatório para todos (N IETZSCHE, 1878b, p.48).

Pode-se notar, enfim, que a origem da linguagem encerra uma pergunta que, para esses três autores, tem de ser considerada. Evidentemente, não nos termos que o diálogo platônico a apresenta, já que sua sagaz estrutura retórica embute em sua pergunta pressupostos a serem dispensados do ponto de vista dos objetivos dos autores aqui mencionados. A o contrário, o esforço que permeia a discussão por parte deles está em desmistificar a explicação pela origem, ou seja, em destituir a proveniência de seu estatuto de fundante. Com esses autores, não se vai às origens para desvelar sentidos até então ocultos ou encontrar determinações transcendentes.

Impossível não lembrar aqui de Foucault, em seu ensaio $\mathrm{N}$ ietz sche, a geneal ogia, a história, quando nos adverte que a pergunta pela U rsprung não se move pela tentativa de retroceder no tempo para redescobrir o sentido oculto para recuperar a essência originária:

Procurar tal origem é tentar recolher o que era 'antes', o 'aquilo mesmo' de uma imagem adequada a si; é tomar como acidentais todas as peripécias que puderam ocorrer, todas as artimanhas, todos os disfarces; é querer tirar todas as máscaras para finalmente desvelar uma identidade primeira. 0 ra, se o genealogista tem o cuidado de escutar a história em vez de crer na metafísica, o que ele aprende? Q ue por trás das coisas há 'al go completamente diferente': não absolutamente seu segredo essencial e sem data, mas o segredo de que elas são sem essência ou de que sua essência foi construída peça por peça (...) (FO U C AU LT, 2001, p.1004). 
${ }^{1}$ Agradeço a Profa. Ana C arolina Soliva Soria que, com verdadeiro empenho de arqueologista, qualidade típica do cioso investigador da psicanálise, encontrou e dispôs em tempo os originais do texto de Fichte para que esse artigo pudesse ser feito.

2 No caso do idioma alemão nem sempre é simples especificar quando se trata de "língua" e quando se trata de "linguagem", já que "S prache" permite ambas as traduções. Por isso, em al guns casos tomaremos distância em relação às traduções consultadas. No caso do idioma francês, não há dúvidas, mas é preciso observar que aquilo que preocupa R ousseau é a origem da língua enquanto sistema articulado e que serve à comunicação, portanto, de uma forma geral, ele se refere à linguagem. $\mathrm{O}$ mesmo ocorre com $\mathrm{N}$ ietzsche, Schelling, $\mathrm{H}$ erder e Fichte. Para simplificar, é interessante que não tomemos a expressão "língua" em um sentido demasia do restritivo.

3 Importante notar que a linguagem é aí compreendida com "arte", o que nos leva a lhe atribuir o caráter de artificialidade.

4 "A dmitamos, pois, que a retórica é a força (dúnamis) de considerar teoricamente o que, em cada caso, é o mais conveniente para persuadir" (AR IST Ó TELES, 1932, p. 73)

$5 \mathrm{G}$ rifos meus.

${ }^{6}$ V on der Sprachfähigkeit und dem U rsprung der Sprache, texto editado no Philosophisches Journal einer G esellschaft Teutscher G elehrten, I ena, 1795. Foi consultada a tradução espanhola de R ita R adll Philipp (Tecnos, M adrid, 1996), mas nem sempre acatada .

7 Grifo de Fichte.

8 “ (...) man muss aus der $\mathrm{N}$ atur der menschlichen Vernunft die $\mathrm{N}$ otwendigkeit dieser $\mathrm{E}$ rfindung ableiten; man muss darthun, dass und wie die Sprache erfunden warden musste" (FICH TE,1846, I, p. 350). 0 bs: grifos meus.

${ }^{9} \mathrm{Grifo}$ de Fichte.

10 "G eschlechtsbegriffe", p. 318/ 293.

${ }^{11}$ Ver FICHTE, 1846,II, “D as D auernde” ,p. 320/ 296.

12 Grifos meus. "N ur ein Product der E inbildunskraft. A uf dieses Substrat wird nun dasW ort seyn oder ist angewendet". (FIC H TE,1846, p. 294/319.)

13 "Trieb"

14 Ver, por exemplo, Gaia Ciência, \# 354 p. 217: “D ito condsamente, o desenvolvimento da linguagem e o desenvolvimento da consiência (...) vão de mãos dadas".

15 "Z um Schluss W orte von Schelling (A bth. II, B B.I, S. 52): ' D a sich ohne Sprache nicht nur kein philosophisches, sondern überhaupt kein menschliches B ewusstsein denken lässt, so konnte der $\mathrm{G}$ rund der Sprache nicht mit B ewusstsein gelegt werden; und dennoch, je tiefer wir in sie endringen, desto bestimmer entdeckt sich, dass ihreT iefe die des bewusstvollsten E rzeugnisses noch bei weitem übertrifft. "' (N IETZSCHE, 1921, p.470). A referência dessa citação é: SC HELLIN G,1985, parte I, lição 3, p. 62.

${ }^{16} \mathrm{~A}$ obra em questão é: A bhandlung über der U rsprung der Sprache. 


\section{2}

${ }^{17} \mathrm{~A}$ tradução de "D raengniss" por "impulso" é bastante infeliz, pois pode gerar confusões com a noção, a ser posteriormente formulada por N ietzsche, de "Trieb". No entanto, não me parece haver outra alternativa, já que termos como "ímpeto" ou "estímulo" se distanciariam demasiadamente do sentido quase fisiológico com que o termo é usado aqui.

18 P. Lacoue-Labarthe nota que a teleologia foi o tema a que mais se ateve $\mathrm{N}$ ietzsche em suas leituras de Kant. Há indícios bibliográficos de que seu estudo mais detido deste autor limitouse à C rítica do Juízo e, de resto, $\mathrm{N}$ ietzsche teria seguido as referências de Schopenhauer.

19 Vom U rsprung der Sprache termina com o seguinte trecho do texto de Schelling anteriormente mencionado: "Sucede com a linguagem o mesmo que com o ser orgânico; cremos que sua formação é devida ao cego acaso, e no entanto podemos seguir até os menores detalhes a insondável finalidade desta formação" (op. cit. , I, L. 3).

\section{Referências bibliográficas}

AR IST Ó T ELES. 1932. R hétorique. Tradução de J. D oufour. Paris: Les Belles Lettres

FIC HTE, J.G. 1846. Von der Sprachfähigkeit und dem U rsprung der Sprache In: SämtlicheW erke, A b. III, Band III. Belim:Veit und Comp.

. 1996. Sobre La capadidade linguística y el origen de la lengua.

Tradução de R ita R adl Philipp. M adri:Tecnos.

FO U C AU LT, M . 2001. N ietz sche, La généalogie, I'historie. In: D its et É crits, v.I. Paris: Gallimard.

LAC O U E-LABARTHE,P. 1971. "Le Détour". In: Poétique, nº 5. Paris: Seuil

N IET ZSC H E, F. 1921. Vom U rsprung der Sprache. In: G esammelteW erke, Band IV. M unique: M usarion

, 1978a. A gaia dência. In: 0 bras incompletas. Tradução de R ubens R odriguesTorres Filho. São Paulo:Victor Civita , 1978b. Sobre verdade e mentira no sentido extra-moral. In: 0 bras incompletas. Tradução de R ubens R odriguesTorres Filho. São Paulo:Victor Civita PLAT Ã O, 1967. C ratyle.Tradução de E. C hambry. Paris: Flammarion 
RO U SSEAU, J.J., 1990. E ssai sur l'origine des langues. Paris: Gallimard 1973a. D iscurso sobre a origem e os fundamentos da desigualdade entre os homens. Tradução de Lourdes G omes M achado. São Paulo:Victor Civita

.1973b. E nsaio sobre a origem das línguas. Tradução de Lourdes Gomes M achado. São Paulo:V ictor Civita SC HELLIN G, F.W.1985. E inleitug in die Philosophie der M ythologie. In: A usgewählte Schriften, B and V. Frankfurt: Suhrkamp.

. 1998. Introduction à la philosophie de la mithologie.

Tradução de J.-F. C ourtine e J.F. M arquet e outros. Paris: G allimard.

ST AR O BIN SKI, J. 1991. Jean-Jacques R ousseau: A transparência e 0 obstáaulo.Tradução de M aria Lúcia M achado. São Paulo: Schwarcz. 